\title{
Japan's Education System, And its financing
}

\author{
Mohamed Elasmay Mahrouse \\ Faculty of Education, Sohag University 82524, Sohag, Egypt.
}

DOI:

\begin{abstract}
The current article provides general features about the Japanese experience in the educational system and the inputs to its financing and spending, as the Department of Education in Japan is characterized by complementary between centralization and decentralization by providing double budgets for the advancement of education, so that the local authorities contribute almost half of the education expenses. Also, the amount of government spending on Japanese education exceeds about $20 \%$ of the total national income, and these funds are often used well to serve the educational process. The local (municipal) municipal authorities participate in the central government in financing education, and each local authority provides the necessary financial support to educational institutions in it. Donations of individuals and organizations play a greater role in financing education, as do financial donation habits from banks, and those who hold funds contribute to financing Japanese educational programs. These financial donations appear to fund educational activities as the end of life nears the Japanese.

This article concluded that Japanese government spending is on educational institutions (both public and private), and financial subsidies are provided to all educational entities, public and private, to students and families, and the private sector there supports educational funding.
\end{abstract}

Key words: Japan's Education System, Japan's Education financing.

\section{Introduction}

Educational institutions, in general, need support and assistance, that is, allocating a set of financial and material resources in advance to educational institutions in order to advance the educational process in them, in addition to raising the efficiency of their work and the quality of services they provide to learners, whether in schools or universities, such as building schools, and its restoration and expansion, with the renewal of school furniture in it, and the

financing of educational activities, according to well-studied and calculated financial plans.

The current article provides general features of the Japanese experience in searching for additional funding sources for its educational system, such as bank donations, stock market taxes, as well as donations from elderly individuals and other community bodies, in order to benefit from this experience in financing education in Egypt. 


\section{Japan's Education System}

The (日本の教育制度: Japan's Education System) is divided into four stages: elementary school, duration of study is 6 years, junior high school, duration of study is 3 years, high school, duration of study is 3 years, and university studies (and junior) College university) for the duration of study in it ranges from 2 to 4 years of study, and there are many private schools, which offer a six-year program that integrates the middle and high school levels, and specialized schools may offer a five-year program that includes high school in addition to two years of Middle college.

There are two options in higher education: middle college (two years) or university (four years). The school year usually begins in April and ends in March of the following year and consists of three semesters: summer, winter and spring, including two short spring and winter holidays, and a one-month summer vacation. As for primary education (it starts at the age of six) in addition to three years of intermediate education - a total of nine years of schooling - it is compulsory (Education in Japan, 2019).

The study (Edward, 1996) has already confirmed that the Japanese education system is considered a model for highly centralized educational systems, as the Japanese Ministry of Education is the center of authority that determines all the details of the course in all subjects, and each curriculum is detailed in precise detail in which the content and the number of hours are determined. Teaching staff. In addition, school books must match the national standards set by the ministry, and the ministry's approval is mandatory for any book taught in Japanese schools, and the private sector has the opportunity to print books and sell them to students.

As for schools, they are managed by the Ministry of Education, and in every region, there is an educational council affiliated with the ministry that controls all schools, and in some areas this council controls secondary schools. As for primary and middle schools, the local council is the one who controls them.

Thus, the administration of education in Japan is characterized by the integration between centralization and decentralization through the provision of double budgets for the advancement of education, so that local authorities contribute almost half of education expenditures, despite the large size of government spending on Japanese education in relation to national income, which exceeds about $20 \%$ of Total national income, and this money is usually used well in the service of the educational process (Esther, Ho, 2006).

\section{Japan's Education financing}

Japan, local (municipal) authorities have participated in the central government - and for decades - in financing education, as each local authority provides the necessary material support to educational institutions in it, through taxes and other sources such as bank donations and stock taxes, as well as individual donations. Authorities 
have the largest role in financing education. They also impose tuition fees as a source of funding for education, between $10 \%-30 \%$ of the proportion of spending on education.

It also provides student loans to students in higher education after they faced imposing or increasing fees on students with strong opposition, as a support system to finance university education, and student loans depend on granting students loans, provided that they are recovered from them after their graduation, and after they obtain Income from work, and there are various ways in the payment process, and the main goal of these loans is to help students and parents educate their children in higher educational institutions and universities (Kenen, 1994).

Solarz (2017) presented an overview of education in Japan during the year 2016, as economic analyzes in the field of education and its financing approaches confirmed that financial donation habits contribute to financing Japanese educational programs and these financial donations appear to finance educational activities with the approaching end of life between The Japanese.

The Ministry of Education (1994) study dealt with the education system in Japan and its financing programs, and the effect of that on the rapid growth of the Japanese national economy, thanks to the addition of advanced industrial high schools and vocational schools, as well as due to the dependence of financial schemes on private financing (28\%) Of the amount of education financing.

This study has clarified the size of educational spending in Japan, along with other sources of funding, as well as the volume of spending on each of the educational inputs (teacher, building, equipment, and equipment) in order to reach the extent to which the planned educational goals are achieved in the different stages of education.

Among the most prominent findings of this study was that the size of public spending on education in Japan in 1993 reached (5158 billion dollars: $7.16 \%$ of the state budget), and at a rate of $(9.5 \%$ of the Japanese national product, and this huge size) The expenditure on education had an important impact on the rapid growth of the Japanese national economy, and the achievement of large jumps in its sectors.

Burton and Clark (2006) also dealt with an analysis of the sources of funding for education in Japan, as a large proportion of the national income there is spent on education from a long time ago, and therefore the large spending on education was what led the state to build a wide base of thinkers, experts and technicians. The Japanese people spend more than $12 \%$ of their entire national budget on education.

In the World Development Report for the year 1990, Japan's allocations in the field of education from the general budget amounted to $5.16 \%$, which confirms the interest of the Japanese and their eagerness to provide high-quality educational service. In general, more than twothirds of educational spending in Japan goes to 
the compulsory stage, and about one-fifth to private education.

Although the proportion of spending or expenditures for each student is determined to the ratio of family income in relation to education in technical colleges, about one-fifth of the national spending is directed to private schools.

Whereas, basic education is provided free of charge to the pupils, and yet the Japanese family participates in some expenditures amounting to about $11 \%$ of the value of total spending on primary education, $15 \%$ of the value of total spending on the lower secondary level, and about $5.23 \%$ of the total spending on the stage In high school, however, the amount spent on education by the government in Japan is much greater compared to what parents pay for their children's education activities, whether in public education or in higher education.

The scientific plans for educational development in Japan, after being guided by the opinions of universities there in 2006 AD, which identified priorities for educational reform in focusing on transforming the educational system into a multi-track system, after the free and compulsory basic education stage (3-6) wherein the institutions are varied and varied in it. Education choices for students, more and more institutions provide educational opportunities, and private education takes an increasing role in investing in education. The total government expenditures on school education in 2012 amounted to nearly 26 trillion yen, of which $85 \%$ was spent on compulsory education: primary and intermediate.

As for local governments, they spent on the first 8 trillion yen, and on the second 4 trillion yen, while the School Union Organization spent about 4 trillion yen, and then government and local spending came in high on compulsory education, followed by higher secondary education, and kindergarten respectively. Japan has allocated nearly 4 trillion yen ( $\$ 35.6$ billion) in the state budget for the fiscal year 2018, for measures focusing on education as part of a strategy to stimulate growth (William, 2014).

While these funds are allocated for the development of Japan's growth strategy, the government has limited spending in other areas such as public works by $10 \%$ from the fiscal year 2018 AD, this amount (4 trillion yen) was spent on steps that include sponsoring the talented and make education free by allocating the money that was saved by reducing government spending in other service sectors (Kajimoto, 2018).

According to the statistics and indicators (OECD, 2018), Japanese public spending on education has been monitored relative to the total GDP there, as the total public spending on education relative to the gross domestic product (GDP) in Japan was at $3.5906 \%$ in 2014, and according to the related group of development indicators For the World Bank, which were collected from officially recognized sources, public spending on education as a percentage of GDP in 2016 was $3.5 \%$. And despite this reduction in Japan's public spending on education 
as a share of GDP in recent years, it tends to increase during the period from 1993 to 2016, ending by $3.5 \%$ in 2016. This includes public spending on education: spending Governmental education institutions (both public and private), education administration, subsidies to private entities, students, families and other private sector entities in education.

Concerning financing private education in Japan, the OECD (2018) reports stated that only (5\%) of Japanese schools are considered private, and that $(71.3 \%)$ of students in these schools have to pay the costs of education in them, while international schools Available in most large cities, these international schools are not accredited by the Japanese government nor provide funding for them:

International schools (not certified by Japanese Governoment)

- The American School in Japan.

- The Canadian Academy.

- Christian Academy in Japan Columbia International School.

- German School Tokyo Yokohama.

- International Christian Academy of Nagoya.

- Academy, And many others (Japan, 2018).

\section{The Summary of The Japan's Education} System, and its financing

From a review of Japan's experiences in financing education: its opportunities, alternatives, and requirements for improving it in its educational institutions, we draw the following conclusions:

- The Japanese education system is considered a model for highly centralized educational systems. As for schools, they are managed by the Ministry of Education, and in every region there is an educational council affiliated with the ministry that manages all schools, and in some areas this council runs secondary schools, while primary and middle schools are administered by the local council.

- The administration of education in Japan is characterized by the integration between centralization and decentralization, by providing double budgets for the advancement of education, so that local authorities contribute almost half of the educational expenditures.

- The size of government spending on Japanese education exceeds about $20 \%$ of total national income, and these funds are usually well used in the service of the educational process.

- Local (municipality) authorities participate in the central government in financing education, and each local authority provides the necessary material support to educational institutions in it, through taxes, bank donations, and other sources of income.

- Donations from individuals and organizations play a greater role in financing education. Tuition fees are imposed as a source of funding for education, between 10 
$\%-30 \%$ of the proportion of spending on education.

- Financial donation habits from banks and money holders contribute to financing Japanese educational programs, and these financial donations appear to finance educational activities with the approaching end of life among the Japanese.

- More than two-thirds of educational spending in Japan goes to the compulsory stage, and about a fifth to private education.

- Japanese families share some expenditures in the field of education financing, amounting to about $11 \%$ of the value of total spending on primary education, $15 \%$ of the value of total spending on the lower secondary level, and about $5.23 \%$ of total spending on the upper secondary level.

\section{References}

Burton, R. Clark, 2006. The Research Foundations of Graduate Education: Germany, Britain, France, United States, Japan. oxford: University of California Press.

Esther, Ho, 2006. Educational decentralization in three Asian societies: Japan, Korea and Hong Kong, Journal of Educational administration 44(6): 590-603.
Education in Japan, 2019. Japan's education system.

https://en.wikipedia.org/wiki/Category:Education_ in_Japan

Edward R. B, 1996. Japanese and US Education Compared, Phi Delta Kappa Educational Foundation, USA.

Japan, 2018. Governance and Accountability, OECD, Education at a Glance 2018, http://ncee.org/what-we-do/center-oninternational-education-benchmarking/topperforming-countries/japan-overview/japansystem-and-school-organization/.

Kajimoto, T. 2018. BUSINESS NEWS. Newspapers published in Japan.

Kenen, M. D. 1994. the impact of reaganomics on state financing of public higher education, university of Massachusetts, diss, abs., int., vol.55, No.3A.

Ministry of Education, 1994. Science and Culture Education in Japan. Japan, Gyosei Coporalion.

Solarz, J. k. 2017. Financial education in Japan, Journal of Insurance, Financial Markets and Consumer Protection No. 25.

William K. Cummings, 2014. Education and Equality in Japan. Princeton University Press. 